\title{
Propositions for the Development of the Public Grievances Commission (A Korean Style Ombudsman)
}

\author{
KIM, KWANG-IL
}

Chairman of the PGC

\section{I . Introduction: the Purpose of Study}

The ombusdsman originated in Sweden as a substitution for the Parliament practiced a role of superintending the administration in its beginning, but now the office operates both as a commissioner of the people and the arbiter between the government and individual and also as an institution aims at the realization of efficient redress and justice. The office is expected to practice a function of disposition of the complaints on the principle of equity with relative ease and promptitude.

After the ombudsman had originated in Sweden in 1809 as a Parliamentary commissioner Finland adopted the office in 1920, but the interests in the office became widespread only after the mid-20th century and at present about 50 countries have introduced the institution. In case of our country the Public Grievances Commission (hereafter described as PGC), Korean style ombudsman, was inaugurated in 4 April 1994 under the provision of the "Basic Law about Administrative Regulations and Civil Affairs Administration" (hereafter described as the "Basic Law.") that has passed in a regular session of the National Assembly of 1993 . The office now is not only in the way of becoming a domocratic controlling agency against the administration but also has a role of dispatching complaints with ease and promptitude in view of the public and thus gradually is in making progress in that it secures its existing ground by performing the role on the one hand and by becoming a democratic controlling agency true to the name.

To consider the siginificance of the legislation of the "Basic Law" that in turn has 
provided legislative basis of the Commission: first of all the law, different from former experiences, had established a system of law aims at the systematization of the basic constituents necessary to remind the government of fairness, clarity, and rationality in performing administrative services for public welfare. Furthermore, it might well be said that the Commission is a symbolic institution of reformative enactment of legislation of the New Government and the institution also has in its provision the pre-screening system against all the newly-made restrictions (or regulations). In other words, through its controlling functions against the government's state of disposition of the civil petitions, and redressing the complainants' grievances infringed upon by unjust and illegal administrative abuses, and having a function of recommendation with corrective alternatives to the administrative system, the office has provided the institutional framework that is helpful in rennovating administrative opportunism. The law is one of the essential reformations of the New Economy for the purpose of relaxing restrictive regulations pledged by the new Government after it had launched.

With these aspects in mind, the primary aim of this study is to propose reformative policies for the consumation of functions of the Commission by way of surveying the "Basic Law" for the Commission and its Enforcement Ordinance.

\section{General Theory of the Ombudsmanic Commission}

\section{Characteristics and Types of the Ombudsmanic Commission}

The ombudsmanic commission had been adopted in a limited countries such as Sweden and other North-European countries, but after the World War II the office was adopted in the developed countries to say nothing of in the developing or underdeveloped countries. The inclination is on the way of rapid spreading around the world. This trend reveals the fact that with the extention of administrative functions there are inevitable relative weakening of legislative functions. That is, the phenomenon is the fruits of the institutional effort to fill up the depleted administrative redress system and to control the administrative bureaucracy enjoyed overwhelming position with respect to its capability in manipulating information, speciality, and technical and material resources and in many other respects.

While in the term 'ombudsman' is included disposition of complaints and grievances, each country has its peculiar variants of the office with slight alterations in its name and function according to their constitutional characteristics. There are, however, not without common characteristics among them and they could be listed as follows.

1) The ombudsman stands independently and neutrally against both the Executives and the Judicature. 
2) The commissioner is appointed among the men equipped with superior judicial and administrative understanding and he is supposed to be a man of noble character.

3) The services in his charge covers manifest illegal act, injustice, inefficiency, profiteering, dereliction, nonacceptance, delaying of disposition, partiality in disposion, etc.

4) The office, different from a lawcourt or the managing administrative government, has no direct right to cancel or change or supervise administrative processes. The ombudsman can only demand or recommend.

5) With the merit of comparative openness in that the office requires no formal procedure in dispatching complaints, it has an advantage of prompt disposition of the businesses compared to administrative litigation.

6) Because the office dispatch complaints about administrative action without legal procedure, the most of cases are free and in no need of attorney. As a result, the system has an advantage of light expenses.

7) The commissioner makes an annual report centering primarily on the annual services and announces it. As in the report are critical evaluations of decisions, recommendations, the sum of protests, it in turn has an immense influence upon the administration.

8) The ombudsman primarily is in charge of the disposition of grievances inflicted upon the individual by the administrative abuses.

Despite of these general common characteristics, the ombudsmanic commission has various appearances according to each country's different political, social conditions. These appearances could broadly be categorized as follows.

\section{1) A parliamentary proper type}

This type is adopted in such countries as Sweden and other North-European countries. The commissioner, appointed in the Parliament and is under the direction of the Parliament, is guaranteed with higher political independence and doesn't interfered by the Parliament. He is supposed to recommend the reform of administrative affairs and to conduct an official reprimand of corrupted civil servants and anticipated to submit an annual report to the Parliament.

\section{2) A modified Parliamentary type}

This type is adopted in the British Commonwealth of Nations. Compared to the parliamentary proper type, this type has its authority and independency immensely restricted. Having a characteristic of a subsidiary organ to the Parliament, the office receives complaints by the hand of the member of the Parliament and notify the results of the investigation to the Parliamentary members. It is expected that the office is responsible for the Parliament. 
3) An executives type

This type is adopted in some developing countries and in several states of the U.S.A.. The primary functions lie in redressing complaints by investigating the accused administrative body through recommendation, persuasion, or mediation. For this reason, it is rather regarded as an administrative proceeding positively contributing to the improvement of the administration through the examination of causes than an adminstrative control by the Parliament.

4) An eclectic type

A representative country adopted this type is France. The office is anticipated to submit report to the Parliament and to the President. This type has an eclectic characteristic of the Parliamentary proper type and the Executives type.

5) A Board of Audit and Inspection type

This type is adopted in Israel. Besides the right of auditing, the appointed inspector has a right of inspecting the efficiency of dispatching civil affairs, reasonableness, and even morality of the civil servants. Consequently, the system makes it clear that the office or the commission has the integrated function of inspection and investigation of civil affairs.

In case of our country the Commissions (while it is an Executives type, it also has an aspect of a collegiate committee) performs above mentioned functions. Table 1 shows comparative table with regard to the differences and commonnesses of the above mentioned types.

\section{Primary Functions}

As explained before, the ombudsmanic commission of each country shows different nomenclatura and functions according to each country's historical, political situation. The services, however, are largely centered around its traditional and essential functions of the ombudsman and several additional functions are added to them in management of the office.

Above all, the office has the function of controlling administration which meant to replenish traditional legislative judicial control system by way of redressing injustices and illegitimacies. Generally speaking, the ombudsman in dispatching complaints and grievances appeals for the purpose of supervising administrative organ is invested with the right of investigation, and the trend is on the way of growing by the establishment of the right of investigaton ex officio.

Secondly, the office has the function of administrative redress which dispatches relief 
steps with ease and promptitude in case of the infringement of the rights and interests of the public caused by illegal and unjust administrative action. With the increasing varification of the functions of the administration, the aspects of conflicts are more broadly extended and the necessity of redress is more and more in need. Needless to say, in our country, though the chance of possibility to enter the court is opened, the possibility felt by the public is in most cases far from satisfactory. Besides, increasing complaints are in the state of an excess of demand in proportion to the ordinary capability of the court to settle. In this context, the introduction of the ombudsmaninc commission could be understood as an alternative measure for resolving conflicts caused by administrative abuses without violating the independency of the Judicature. Especially the function of arbitration of the ombudsmanic commission has a significant meaning with regard to the avoidance of judicial procedure of litigation. That is, without just insisting blindly opposing assertions between the parties concerned, and by giving aids to create a positive relationship between themselves and at the same time by suggesting alternatives helpful to create an agreement, the office verifies the possibility that it can conduct more desirable and wise settlement than that conducted by the court.

Thirdly, the main function of the ombudsmanic commission is to find out problems in management and in the administrative system through the investigation and analysis of the public grievances, and thus performs the role of improvement and reform in administrial management by way of suggesting objective and rational rectifying alternatives in the position of the third executive body. The ombudsmanic function as a reformer has a significance in that it can achieve the change of the administration through humane, "a soft law" without depending on a special authority. The "soft law" here means and tends to be a service-oriented and largely recommendatory to make civil servants do their best in doing their services toward the public. While giving motives to the administrative body, the law can provide various channels for communication between the government and citizen. Consequently the "soft law" can be a good precedent or a guiding principle for the administrative organs intending to use the similar measures and when to consider all the legal measures aiming social coexistence in a democratic country it might be said that the law is most human of all.

Nowadays citizen no more obeys blindly to the public administration. They want to participate in and make a protest to the administration related to their own interests and rights. As a result the need of an effective linking line that can properly answer for their attitudes is in great demand. The last function of the ombudsman is to perform the very role. That is, the ombudsman announces administrative fallacies to the public and can explain and convince just and right administration. In other words 
the ombudsman is the spokesman both of the government and citizen. To secure an efficient management, therefore, from the very moment of launch of the office it is necessary to take a proper step to ensure independence from political, administrative influence through endowing powerful authority to it.

\section{The Background of the Introduction and the Present State of the Public Grievances Commission}

\section{The Background of the Introduction}

Section 1 of the "Basic Law" makes it clear that the purpose of the said law's legislation is "to protect the rights of the people and to manage a fair administration by providing elementary provisions related to the administrative regulations and civil affairs administration, and by diminishing inconveniences and injustices on the public resulted from the mis-doings, and by attempting consistent improvement of the administration." The Commission established by this law has the following background of the introduction.

1) In spite of consistent attempt for the simplification of the civil affairs businesses and the relaxation of the administrative regulations, the administrative opportunistic system and attitude still remains and inconveniences and complaints of the public are increasing.

2) Despite sustaining relaxation and abrogation of the preexisting regulations, the lack of restraining machinery caused cumulative rising administrative regulations and complaints.

3) Though there exist civil affairs offices such as the Office of Civil Administration Secretariat of the President, the Prime Minister's Secretariat, the Incorporated Governmental Civil Affairs Office. etc., these organs give largely the impression that they merely are perfunctory procedural body. For this reason the necessity of institutional support for securing the third executive body which can resolve and dispatch complaints positively in view of complainants is increasing.

4) There being exist various organs such as the Incorporated Governmental Civil Affairs Office as grievances commission, and administrative judgement and administrative litigation as a judicial relief system, and the Parliamentary inspection of the administration and the audit and a system of petition of the National Assembly, and the Board of Audit and Inspection as a Constitutional institution. But in reality they are insufficient to take charge in the individual, tangible disposition of complaints in view of the people. Accordingly there is a great need of the third incorporated administrative body which has an objective viewpoint (or rather the people's point of 
view) which can face complainants with "human face and warm heart," and which not only dispatch complaints that cover such broad cases as illegal and unfair disposition of administration, rejection of appeal application, delaying of disposition, negative administrative action (including an act de facto), and the cases that causing inconveniences and strains by unreasonable institution or measure, but also can draw out rectifying measures tallying with the purpose of the legislation.

On the basis of these necessities, the Administrative Reform Committee, a Presidential advisory organ, proposed the legislation of the "Basic Law" which in turn operated as a foundation of the Commission in May 1993. Through several inter-governmental conferences and discussions of the Assembly, the "Basic Law" was announced in January, and entered into enactment from April 1994.

\section{The Constitution and Authority of the Commission}

Paragraph 4 of Section 2 of the "Basic Law" defines its primary subject of complaints as " the public grievances against the cases which inflict inconveniences and strains to the public or the cases of violation of rights caused by unreasonable administrative system and illegal, unjust, negative administrative action (including the act de facto, forebearance) of the administrative body." The law, to protect the rights and interests of the public by way of supervising the progress of the businesses and receive and dispatch complaints with ease and promptitude, opened the Commission attached to the Prime Minister's Office and the Commission should has a charateristic of an independent collegiate committee. The said Commission is constituted 5 members including 1 chairman, and is invested with independency in dispatching businesses by providing the provisions for the guaranteeing of the members' status by the law. The authority of the Commission is as follows: 1) consultation, investigation, and disposition of the complaints, 2) recommendation of rectifying measures against illegal, unwarrantable proceedings after the investigation of the complaints, 3) recommendation or proposition against (or about) the improvement of the management and administrative system, 4) notification of results of the disposition of the accused administrative body in response to the recommendation proposed by the Commission, etc.. The businesses of the commission are only to recommend and has no power of judicial execution. But through the above mentioned right of notification of the results of the disposition, and of report to the President the commission is guaranteed its executive power indirectly. 


\section{The Consumation of Administrative Functions of the Commission and Its Mal-function Causing Factors}

To consider the shortcomings of the Commission broadly after the launch, though it is relatively short span for valid evaluation. The main restrictions might well be divided into two categories: 1) judicial, institutional restrictions, 2) managerial restrictions.

\section{Judicial, Institutional Restrictions}

(1) The Problem of the Legislation of A Separated Law

In case of foreign countries the basis for the establishment of a commission is provided by the Constitution or an independent special law, while basis for the Commission is provided by the "Basic Law" without any definitive details. Of course it might be deemed as a progress if compared to the tiem when civil affairs busiesses were grounded and dispatched by the Presidential Ordinance without a mother law. In respect to the characteristics of businesses, however, despite the need of systematic provisions which define the establishing basis, the boundary of the businesses, and other requirements, the "Basic Law" and its Enforcement Ordinance provide these provisions in a mess and there are even considerable ommission which shouldn't be. Thus, consequently, the law constitutes an extremely vague legal system. For example, the provision about the budget and administrative backup of the Commission is ommitted or attached to the Ministry of Government Administration, and by making the official ( commissioner) of the Ministry of Government Administration hold concurrent post for the Commission provokes the problem of dependency.

(2) The Problem of the Extent of Jurisdiction

Section 16 of the "Basic Law" which defines indiscriminately the exception clauses for the jurisdiction of the Commission has perfunctory, restrictive elements in view of the purpose of the redress, and wants strenuous study. Especially, the provision for avoiding duplication with regard to other redressing procedure, or the provision about the interest-related case is suspicious of its positive affectuation in that the case is only to be found after the investigation.

(3) The Problem of Manifest Legislative Fallacy

Section 26 of the said law see to it that "[the Commission] can recommend corrective alternatives (or suggestions) when there is considerble reasons enough to recognize the administrative action as manifestly illegal and unjust act." The problem 
of that Section lies in that is does not acknowledge or recognize the instrumentality of redressing rights and interests in case of the infringement of the rights by forebearance or unreasonable institution.

(4) The Problem of the Attachment and the Procedure of Appointive Approval

The problem of to where the Commission should be attached, whether to the Judicature or to the Executives, and how to provide the steps for the appointment of the commissioners, are important in securing the position and independency of the said Commission. In case of the said Commission, while its primary attachment is to the Prime Minister's Office for the purpose of ensuring the efficiency through many a convergence or gathering of the opinions, supplementary businesses are ordained to be conducted in the Incorporated Governmental Civil Affairs Office of the Ministry of Government Administration, and the appointment of the commissioners is in charge of the President. Compared to the cases of foreign countries, however, to make sure and keep political, administrial independency, the measure intending the building of more independency and the reinforcement of more authority by virtue of the revision of the Constitution is inevitable in view of long-term consideration.

\section{(5) The Problem of the System of Non-Standing Commission}

The Commission at present is constructed with a standing commissioner and four non-standing commissioners, and their tenure is 3 years and they can be reappointed one more time only. But the great amount of congestion of the businesses accepted after the launch of the Commission makes it impossible to conduct regular services with present system of construction of the Commission. Furthermore, when considering the similarities of the characteristic of the Commission to that of the Board of Audit and Inspection and to the Central Election Management Committee, both are collegiate independent special administrative body, it is important to reconsider the permantization of the commissioners and the extention of their tenure and the replenishment of the member of the Commission.

\section{(6) The Problem of Securing A Separated Organization of Business}

At present all the staff and the investigators of the Commission are constructed with the officials expedited from the Ministry fo Government Administration or other bureaus and departments to the Incorporated Governmental Civil Affairs Office. The Commission, accordingly, is in a state failed to secure independent organization of business and the right of personnel management and the right of execution of the budget. This means that the investigators that should originally perform the function of investigation and then disposition of the grievances of the public in the view of the 
third independent position, however they in reality have the possibility of becoming the official of the accused bureau or department and thus have the possibility of hampering fundamentally the fair and impartial disposition of complaints.

(7) The Problem of the Expert Commissioner System

As the contents of the accepted complaints cover almost all the sphere of the businesses of the bureaus and departments of the government, it is essential, in investigating and analysing the complaints, that the investigators ought to have the speciality and accumulated experiences and with the capability of research and study to say nothing of comprehensive knowledge of (about) the reform of the institution. But Section 22 of the "Basic Law," while providing the provision that the Commission, in case of necessity, can appoint expert commissioner, does not define the number of person, the status, and remuneration of the commissioner and thus remaind ineffective in practical point of view. Therefore, to gather experts from the various fields to cope with the ever changing and specilizing administrative expediencies, the provisions concerned with the guaranteeing of the status and with the procedure of appointment of the commissioner should be added with more detail and clarity.

\section{Managerial Restrictions}

(1) The Shortage of Investagators and Working Conditions

Now public expectation regarding to the newly established Commission's function is very high and the more reconsidered the degree of the recognition of the people to the Commission's functions and activities, the more, it is expected, the accumulation of the businesses will be overcrowded. Furthermore, as the procedures of the Commission in dispatching the business is simplified 4-5 times as compared to those of the Incorporated Gocernmental Civil Affairs Office previous, there is a proportionate increase of businesses and the trend makes the supplemetation of the personnel inveitable. In addition to this, since the working places of the Commission is decentralized into the Commission and working place, it also results in inefficiency in disposing the complaints with ease and promptitude.

\section{(2) The Problem of the Morale of the Investigating Officials}

As the recognition of the bureau and department of the govenment and the administrative body as to the role and function of the Commission is still in poor state, and, in response to the inefficiency of disposing business (it in some respect is inevitable, especially when we consider the construction and particular condition the Commission is situated) resulted from the lack of the sense of attachment and 
competency of the officials attached to the Commission, it is necesary to frame up a morale-building measure. According to the characteristics of the business, the commissioner in charge of the office, while has to face the public filled with complaints, should remain as the public interests-oriented. Besides, he should deal with the cases directly related to his primary attached organ's interests. Consequently, the commissioner is to be always in an extreme condition of tension. In this respect the proper compensation and endowment of additional award marks in personnel affairs, a special investigation allowance should be conferred for the pains of the commissioner. But the abrogation of the system of additional award marks endowment in 1996 has a great bad influence upon the morale of the officails. The reason of the repeal is to establish the principle of the merit system. The reason, however, is brought by ignorance about the particularities of the Commission's businesses, and should be reconsidered. Ordinary officails' reform of consciousness and lack of understanding could be overcome through consistent education about the purpose and by the acts of the Commission. But it is umpossible to expect the consumate administrative function of the present Commision without graranteeing and securing the improvement in personnel management with favorable treatment after expeditionary services and without decreasing the execessive amount of the affairs for the investigators during expeditionary services.

\section{Propositions for the Development of the Commission}

\section{A Short-Term Proposition for the Development.}

(1) The permanantization and the Guarantee of Status of the Commissioner by Law

For the purpose of the more exhaustive discussion of and introduced cases and the disposition of accumulating excessive complaints, it is necessary to permanentizing the chairman and the three of the non-standing commissioners, especially the status and the remuneration of the commissioners should be guaranteed by the law. The chairman should be accorded an honorable treatment and paid up to (or above) the level of a Minister of State or the level of a Justice of the Supreme Court. It is also desirable to ensure by the law that the commissioner should participate in the State Council and express his opinion about related businesses. The commissioner should be secured the status up to the level of a Deputy Secretary according to the characteriasics and businesses of the office in case if he is a standing official. Again, the present tenure of the commissioner ( 3 years and could be reappointed only one time) should be prolonged to 5-6 years and, through this, ensure the speciality of the officials. In addition to this, it is necessary to secure the sustenance and the 
independency of the services by way of election by relay or by making the term of the offices intertwine with that of the President. Finally, the endowment of the privilege of exemption of liability in respect to the investigation and discussion of the Commission will be helpful in securing the more free and objective attitude of the Commission.

(2) The Clarification of the Commissioner's Right of Proposal

While the present Commission is attached to the Prime Minister, the appointment of the chairman and the members of the Commission is performed by the President without the proposal of the Prime Minister, and the report of the Commission is ordained to be submitted to the President. As a result, the constitution of the Commission betrays discrepancy between the laws and regulations for organization and actual management of it. Compared to the Fair Trade Commission attached to the Economic Planning Board, while the Fair Trade Commission Recognizes the social authority of the commissioners by enhancing its criteria of qualification and requirement, that of Commission is relatively low and unsatisfactory in proportion to its degree of contribution to the society. It is, therefore, necessary to secure the Commission's status definitely by reinforcing its regulations for qualification corresponding to the actual conditions.

(3) The Right of Personnel Management of the Chairman and Securing of the Right of Compilation of the Budget.

Once the fact that the Commission is independent administrative body is accepted, the indepentdent right of personnel management of the chairman for the manager and expert commissioner of the Commission and for the staff of the independent office and the right of compilation of the budget should accordingly be insured. In these respects the present customary practices of compilation of the budget of the Commission as a subsidiary budget of the Ministry of Government Administration should rapidly be improved.

(4) The Reinforcement of and Morale Work of the Expert Commissioner

When thinking the increase of demand for the sphere of sanitation, welfare, health, environment, traffic, and eductaion, it is necessary to reinforce the number of expert commissioner and to insure a measure for securing status of the commissioner to cope with ever specializing administration. Especially, functions related to the investigation, analysis of concrete administrative action of the State, improvement of the system, announcement, report to the President, the need of expert commissioner is essential and it also is essential to complement the institutional limit for the independency of 
ordinary investigators. Therefore, it is inevitable to hope for the stability and speciality of the Commission by open employment of experts according to their majors on the one hand, and by providing proper remuneration and measure for security of the status enough to keep the commissioner from financial problem or insecurity of status which dosen't concerned with the business on the other. These considerations should indisputably be provided in its establishing law or its enforcement ordinance.

(5) The Replenishment of the Investigators and Preparation of the Morale-Building Work

The institutional bases should be provided, which enabling for the Commission immediate request for expeditionary team to the related organs to the effect of proper management of the office according to the amount of businesses which is in a state of suffering from the absolute shortage of the number of the investigators. Needless to say, in long-term respect, it is desirable to grope for the measures helping replinishment of the regular members of able investigators to make it possible that the commissioners can dispose the civil affairs businesses as a separated, independent organ's investigators rather than as investigators expedited by bureaus and departments for a limited term. Besides, for the promotion of the investigators' morale and consumation of the function of the Commission, the

bases of the endowment of honorable treatment and additional evaluation in personnel administration for the expedited officials should be provided in the "Basic Law" separately. Working places now quartered at several places should be incorporated, and the problem of replacing incommodious office room of the investigator and replenishing $O A$ machine necessary to the business should be resolved.

(6) The Construction of Information and Communication Network.

Becoming to the age of couputer-oriented communication, the development of the program which enabling the gathering of the opinion of the public and reception of public grievances through the computerized network system, and replenishment of its managing manpower are to be pegionholed. The acceptance of complaints through the computer-oriented communication system has an advantage in that the method can afford the channels for communication with numerous public of various classes and can not only curtail time and expense but raise intimacy between the Commission and the public. Besides, the method can prevent mischievous applications and uninscribed letter from the outset. Futher, by providing accumulation of materials through the construction of inter network-system and data-basement, more precise and prompt disposition of the complaints come to be realized. 
(7) The Fortification of the Management of Pubicity

While it is true that the ombudsmanic commission and the press is and should be in close connection with each other, the publication of examples of the correcting alternatives and recommendations and the practice of public information with the aid of the press has its limitation. Therefore, it is necessary to ensure the channels for speaking the purpose of the Commission and to publish the periodicals of the Commission to avoid overlapping. Independently of this, it is advisible for the Commission to use mass media in the appearance of the public good-oriented advertisement.

\section{Long-Term Propositions for the Development}

(1) Stipulation of the Commission as a Constitutuinal body

In long-term point of view, it is necessary to stipulate in the Constitution the basis of establishment of the Commission and to prescribe systematically the regulations of the Commission as an independent legislation. In this case, the Commission is to be under the immediate control of the President and the appointment of the chairman and the ordinary member of the Commission woulf be performed by the President and ordained to pass through the procedure of appointment approval of the National Assembly. Thus not only can enhance and back up the high status of the Commission but also avoid the conflicts resulted from the seperation of powers of the Legislature and the Judicature and provide an independent, objective working condition. In addition to this, once provided that the purpose of establishment of Commission is to dispose the civil affairs and complaints of the public as the third independent and neutral administrative body, the right of setting bylaws about the compilation of the budget etc., which is necessary to perform investigation of the investigators and discussion of the Commission and judge for the management, should be conferred upon.

(2) The Establishment of Independent Organization of Businesses and the StreamLining of the Regulations.

The present "Basic Law," without regulations for the establishment of business premises of the Commission, provides the office to have a manager for the disposition of the affairs. But the same law makes it clear that the very manger should be appointed among the official of the Ministry of Government Administration (which has the possibility of becoming an accused body) and the person designated by the President, and keep the chairman of the Commission from performing the right of personnel management. Thus the Commission is exposed to the danger of being a 
kind of spectre organ that cannot ensure indepenent and consistent business. Futher, as the Commission is anticipate to perform a country-wide civil afairs, it is evident that the Commission should suffer from the congestion of applications and provincial petitioners' chance of participation in the procedure of discussion is to be restricted. So to secure prompt, convenient disposition of the complaints and services as an indpendent Commission, it is necessary (or should be possible) to procure the legal basis which can organize concrete body of business and to establish provincial subidvision of the Commission at least in the provincial metropoltian.

(3) The Adjustment of the Sphere of Jurisdiction

With a view to the characteristic of the institution, the review of whether the wholesale exclusion of jurisdiction for the related Paragraphs of Subsection 1 of Section 16 is just on the basis of managerial achievement of the Commission within at a fixed period. Especially, 1) in case of going through other proceeding after the fact to not to lose redress procedure by other laws (such case as the expiration of the instituting date etc.) after the application of the complaints beforehand, the problem of regarding the caes as an without of the jurisdiction, 2) in case of the expiration or porceeding by other judicial operations such as decision or determination which is not the final decree of the court but rather an administrative litigation, the problem of exclusion of the case by recognizing it as a fixed one, 3) in case when the complaints which has an aspect of popular litigation received, the problem of exclusion of the petitioner from the subject of investigation according to Paragraph 2 of Subsection 1 of Section 24 of the "Basic Law," etc., should be reexamined. Besides, it is necessary to add supplementary regulations for the improvement of unreasonable system or other provisions such as forebearance to the subject of Section 26 of ths said law. Furthermore, the phrase like as "in case that there is considerable causes" is advised to be revised as "in case when there is petitioner's urge," or "in case when the petitioner is just" and thus expected to rectify fallacies of legislation with positive attitude. In addition, it is also necessary to prepare a joint confrontation through connection among cases with preexisting organizations for public welfare by including the acts of organized civilians (for example, the arbitrations of corporations, invironmental pollution, inferior goods, etc.) related to the responsibility of the office's management and supervision as the subject of the Commission's investigation and discussion.

To insure efficiency in coping with ever diversifying, specializing administrative process, outside experts or communications chnnels with various private and public organizations should be procured. It is also necessary to procure the budget and the basic regulations in evoking public opinion against the problematic cases by holding various public hearing, seminars, etc., on the very cases and and in offering plans for 
the improvement of the proceeding. In long-term viewpoint, the right of investigation ex officio, which can investigate by broadcasting or by the judgement under the self-auspice of the Commission, should be endowed to the Commission. For more specialized inspection against accepted complaints and for the disciplinary punishment of a corrupt official, it is necessary to establish a relationship with the Board of Audit and Inspection, an independent Constitutionary organ, and to seek measure for collaboration such as the right for claiming auditing to the Board of Audit and Inspection.

(4) An Arrangement for Procuring the Basis of the Local Civil Affairs Ombudsman.

In case of Japan, thogh the civil affairs ombudsmanic commission on the level of the central government does not function, at the town of Kawasaki (a local autonomous entity) and the district of Nakanoku, in Tokyo, the ombudsmanic commission is established and managed by Regulations. In case of our country, the trend, it is expected, will be a growing concern with the execution of a system of self-government in 1995. Accordingly, it is anticipated, the ombudsmanic system on the level of local autonomous body will be introduced and in this case the basis of the mother law is to be necessary to provide provisions for the civil affairs ombudsmanic commisssion by Regulation. To resolve the necessity, the construction between central government and local autonomous body is inevitable and the basis of the establishment of the civil affairs ombudsmanic commission in the local autonomous entity should be provided in the law.

\section{Conclusion}

In the political, administrative history of our country, the legislation of the "Basic Law" may well be evaluated as to have provided a critical moment which cut a chasm in the field of disposition of complaints and grievances. The process of the introduction of the ombudsmanic commission in the administrative climate of our country, however, is not so easy and accompanies with it the conflicts caused by the protection of vested rights and interests between bureaus and departments on the one hand, and preexisting institutions on the other. Consequently, the avoidance of these conflicts in legislation of the related regulations makes it inevitable that the guaranteeing of traditional, inherene authority and power of ombudsmanic commission is rather neglected. In this study, one has surveyed restrictive elements which are largely centered on the regulations of the "Basic Law" and its Enforcement Ordinance in part and on the management of the office in part, and thus has proposed the tentative measures for the further development of the Commission broadly in two: 
short-term propositions and long-term propositions.

When we define the meaning of the term "systematization" as a process of governmental, procedural acquisition of value and stability of a system, the criteria for the evaluation of the politically-organized body's level of systematization are to be its adaptibility, its autonomy, its compositeness and cohesiveness. When an organization acquire its internal compositeness and cohesiveness and, in addition to this, acquire, adaptibility and autonomy in response to the challenge of external circumstances, only then it might be said that the organization is systematized. Therefore to secure the development and systematization of the newly-introduced ombudsmanic commission, social, political, cultural circumstances should be matured simultaneously.

Fundamentally speaking, the problem that to where the Commission should be attached, in my opinion, is not important. It is because, provided that the ombudsmanic commission could work well for the complainants with respect to the country's tradition and practices, the attachment of the commission would be a matter of no importance. The most important thing for effective management of the ombudsmanic commission is to endow a mighty authority and power to the commission after exhausting consideration with regard to the problem of harmony and balance with and among other redressing systems, and this is prerequisite for the domiciliation of the system.

Compared to the other country's ombudsmanic commission, on thinks, the function of the Commission is never in the lower level. For the effective management of the Commission, and to be an organ that can dispatch the great amount of complaints and grievances with ease and promptitude in view of the public with warm hearty affection, the revision of the related legislation and, further, domiciliation of the Commission as a Constitutional body is hoped for.

Finally, emphasizing the fact that the role and function of the Commission as a civil affairs ombudsmanic commission performs a complementary role to the preexisting redressing systems (such as redress, reparation for injury, compensation for loss, administrative judgement, administrative litigation, etc.), rather than overlapping or conflicting, one expects more advanced succeeding study.

\section{Notes}

1) The right of investigation ex officio, which can carry out investigation by the ombudsman's own judgement without application of the complainants or the person (or party) concerned, is recognized in the countries such as Sweden, Norway, Denmark, Austria, (in several districts of) Canada, New Zealand, Italy, Germany, etc..

2) Despite the appointment of 6 expert commissioners in 4, June 1994, it is necessary to replenish 
at least 1 commissioner according to the characteristic of the business of each bureau of department. For reference, there are 26 bureaus and departments in the government of the R.O.K..

3) Section 37 of the Law for the Regulation of Monopoly and Fair Trade.

4) Section 17 of the Basic Law about Administrative Regulations and Civil Affairs Administration and Section 49 of Enforcement Ordinance of the said law. 